\title{
Assessment of the effect of Bacopa monnieri (L.) Wettst. extract on the labeling of blood elements with technetium-99m and on the morphology of red blood cells
}

\author{
Kakali De, Susmita Chandra, Mridula Misra* \\ Department of Nuclear Medicine, Indian Institute of Chemical Biology, 4, Raja S.C. Mullick Road, \\ Kolkata -32, India
}

\begin{abstract}
RESUMO: “Avaliação do efeito do extrato de Bacopa monnieri (L.) Wettst. na marcação de elementos sanguíneos com tecnécio-99m e na morfologia de células vermelhas do sangue." Bacopa monnieri (L.) Wettst. (BM), uma planta tradicional da medicina ayurvédica, é usada por séculos para problemas de memória, antiinflamatória, antitérmica, sedativa e como agente anti-epiléptico. $\mathrm{O}$ extrato BM têm sido extensivamente investigada por diversos autores por seus efeitos neurofarmacológicas. Na medicina nuclear, os glóbulos vermelhos (RBC) marcados com tecnécio-99m $(99 \mathrm{mTc})$ tem várias aplicações clínicas. Entretanto, os dados demonstraram que drogas sintéticas ou naturais podem modificar a marcação de hemácias com $99 \mathrm{mTc}$. Como Bacopa monnieri é amplamente utilizado em medicina, foi avaliada a sua influência na marcação de hemácias e proteínas plasmáticas com tecnécio-99m $(99 \mathrm{mTc})$. Este procedimento de marcação depende de um agente redutor e normalmente o cloreto estanoso é usado. Sangue foi incubado com os extratos BM. Solução de cloreto estanoso e $99 \mathrm{mTc}$ foram adicionados. O sangue foi centrifugado e o plasma (P) e células sangüíneas (CS) foram isolados. Amostras de P ou BC também foram precipitadas, centrifugadas e fração insolúvel (FI) e fração solúvel (FS) foram separadas. A porcentagem de radioatividade (\%ATI) em BC, IF-BC e SE-P foram calculados. A As\% ATI diminuiu significativamente em $\mathrm{BC}$ de $95,53 \pm 0,45-35,41 \pm 0,44$, no IF-P de $80,20 \pm 1,16$ para $7,40 \pm 0,69$ e no IF-BC em 73,31 $\pm 1,76-21,26 \pm 1,40$. O estudo da morfologia de hemácias revelou alterações morfológicas importantes devido a tratamentos com extratos BM. Sugere-se que a ação do extrato BM poderia ser explicada por uma inibição dos íons estanoso e pertecnetato ou oxidação do íon estanoso ou por danos na membrana plasmática.
\end{abstract}

Unitermos: Bacopa monnieri, Scrophulariaceae, tecnécio-99m, células sanguíneas vermelhas, plasma, proteinas, morphologia.

\begin{abstract}
Bacopa monnieri (L.) Wettst. (BM), a traditional Ayurvedic medicine, used for centuries as a memory enhancing, anti-inflammatory, antipyretic, sedative and antiepileptic agent. $\mathrm{BM}$ extract have been extensively investigated by several authors for their neuropharmacological effects. In nuclear medicine, red blood cells (RBC) labeled with technetium-99m (99mTc) have several clinical applications. However, data have demonstrated that synthetic or natural drugs could modify the labeling of RBC with $99 \mathrm{mTc}$. As Bacopa monnieri is extensively used in medicine, we evaluated its influence on the labeling of RBC and plasma proteins using technetium-99m $(99 \mathrm{mTc})$. This labeling procedure depends on a reducing agent and usually stannous chloride is used. Blood was incubated with BM extracts. Stannous chloride solution and 99mTc were added. Blood was centrifuged and plasma (P) and blood cells (BC) were isolated. Samples of P or BC were also precipitated, centrifuged and insoluble fraction (IF) and soluble fraction (SF) were separated. The percentage of radioactivity (\%ATI) in BC, IF-BC and IF-P were calculated. The \%ATI significantly decreased on $\mathrm{BC}$ from $95.53 \pm 0.45$ to $35.41 \pm 0.44$, on IF-P from $80.20 \pm 1.16$ to $7.40 \pm 0.69$ and on IF-BC from $73.31 \pm 1.76$ to $21.26 \pm 1.40$. The morphology study of RBC revealed important morphological alterations due to treatment with BM extracts. We suggest that the BM extract effect could be explained by an inhibition of the stannous and pertechnetate ions or oxidation of the stannous ion or by damages induced in the plasma membrane.
\end{abstract}

Keywords: Bacopa monnieri, Scrophulariaceae, technetium-99m, red blood cells, plasma, proteins, morphology. 


\section{INTRODUCTION}

The use of natural products, as medicinal plants, has increased in the last decades all over the world (Oliveira et al., 2003a, 2003b; Gobindarajan et al., 2005; BarbosaFilho et al., 2007; Biavatti et al., 2007; Cardoso-Lopes et al., 2008; Quintans-Júnior et al., 2008; Rangel et al., 2008; Rodríguez et al., 2008; Sousa et al., 2008; Mariath et al., 2009). Bacopa monnieri (L.) Wettst. (Brahmi) is a creeping annual plant found throughout the Indian subcontinent in wet, damp and marshy areas. Bacopa monnieri (BM) is an important constituent of the Ayurvedic material medica and is used to improve memory, intellect (medhya) and epilepsy. Extensive investigations (Russo et al., 2005; Kishore \& Singh, 2005; Bhattacharya et al., 2000) indicate that the extract of $\mathrm{BM}$ facilitated learning acquisition, improved retention of learning (memory) and to increase the activity of antioxidative enzymes (e.g. superoxide dismutase (SOD), glutathione peroxidase and catalase) (Jyoti et al., 2007). BM extract contains a mixture of triterpenoid, saponins designated as bacoside A and B and number of alkaloids (Singh \& Dhawan, 1992; Chowdhuri et al., 2002; Paulose et al., 2007).

In Nuclear medicine technetium-99m (99mTc) has been the most utilized radionuclide both in diagnosis nuclear medicine procedures and in basic scientific research (Srivastava, 1987; Early \& Sodee, 1999; Saha, 2003; Hladik et al., 1987; Gutfilen et al., 1993; BernardoFilho et al., 1994a, 1994b; Aquino et al., 2007; Paoli et al., 2008; Mousinho et al., 2009). This wide use in nuclear medicine is due to its optimal physical characteristics, convenient availability from Mo-99/Tc-99m generator and negligible environmental impact (Hladik et al., 1987; Early et al., 1999; Saha et al., 2003).

There are several important applications of 99mTc labeled red blood cells (99mTc-RBC), the most important being cardiovascular nuclear medicine. Some other applications include the blood pool of other organs, detection of gastrointestinal bleeding sites, and determination of RBC mass in patients (Hladik et al., 1987; Srivastava, 1987; Callahan \& Rabito, 1990; Gutfilen et al., 1993; Porter et al., 1993; Early \& Sodee, 1999; Saha., 2003; Bernardo-Filho et al., 1994a). RBCs have been labeled with $99 \mathrm{mTc}$ by in vitro (Bernardo-Filho et al., 1983; Hladik et al., 1987; Early \& Sodee, 1999; Saha, 2003; Bernardo-Filho et al., 1994a, 1994b), in vivo (Hladik et al., 1987; Early \& Sodee, 1999; Saha, 2003) or by a combination of these two, called in vivo/in vitro labeling (Atkins et al. 1980; Srivastava et al., 1984; Hladik et al, 1987; Srivastava, 1987; Bernardo-Filho et al., 1994a; Harbert et al., 1996) techniques. Plasma proteins are also labeled with $99 \mathrm{mTc}$ and used for evaluation of lung perfusion and location of placenta (Harbert et al., 1996; Moreno et al., 2002). These labeling techniques involve the pre-tinning of the blood constituents with stannous ions, followed by exposure to $99 \mathrm{mTc}$, as sodium pertechnetate, which is reduced within the cell and remains trapped intra cellularly by the binding in the beta chain of hemoglobin (Harbert et al. 1996; Moreno et al., 2002; Bernardo-Filho et al., 1994a). Sequential steps of the intracellularly labeling process of blood constituents include: (1) transmembrane transport of reducing agent $\left(\mathrm{Sn}^{2+}\right)$ and $99 \mathrm{mTcO} 4$ ions into the internal compartment of the RBC, (2) reduction of $99 \mathrm{mTc}\left(99 \mathrm{mTcO}^{-}\right)$by $\mathrm{Sn}^{2+}$, and (3) subsequent binding of the reduced 99mTc to hemoglobin (Dewanjee et al., 1982; Abreu et al., 2006). The band-3 anion transport system and calcium channels may be involved in transport of these ions (Callahan \& Rabito, 1990; Sampson, 1996).

Unexpected patterns of radiopharmaceutical biodistribution can be associated with a disease and dietary conditions (Oliveria et al., 2002). Any chemical, physical or biological agent which alters the chemical identity of the tracer or modifies the physiological status of the organ of interest or modifies its binding capability to plasma proteins or other blood element could be expected to alter the radiopharmacokinetics and the disposition of the radiopharmaceutical in the specific target (Hladik et al., 1987; Srivastava \& Straub, 1992; Santos et al., 1995; Oliveira et al., 2002; Moreno et al., 2004). The labeling of red blood cells with $99 \mathrm{mTc}$ has been also influenced by patient medications (Hladik et al., 1987; Oliveira et al., 2002).

Authors have reported that many natural or synthetic drugs can alter the labeling of blood elements with 99mTc (Haldik et al., 1982, 1987; Srivastava \& Straub, 1992; Gutfilen et al., 1993; Santosh et al., 1995; Oliveira et al., 1997; Oliveira et al., 2003a; 2003b; Frydman et al., 2004; Moreno et al., 2004; Fonseca et al., 2005). There are some studies about the effect of the medicinal plants (Thuya occidentalis, Nicotiana tabacum, Peumus boldus, Maytenus ilicifolia, Paullinia cupana, cauliflower) on the labeling of RBC with $99 \mathrm{mTc}$ (Hladik et al., 1987; Hesslewood \& Leung, 1994; Sampson, 1996; Oliveria et al.,1997, 2002, 2003a; Vidal et al., 1998; Dire et al., 2003). The drugs (natural/synthetic) could alter the labeling of blood constituents acting as antioxidant agent, modify the membrane structure or decrease the efficiency of transmembrane transport system of stannous and pertechnetate ions into cells (Abreu et al., 2006). In this context, we have evaluated the influence of aqueous extract of Bacopa monnieri on the labeling of RBC and plasma proteins with $99 \mathrm{mTc}$ using an in vitro (BernardoFilho et al., 1994a, 1994b) technique and we have also studied qualitatively the morphology of the RBC under an optical microscope.

\section{MATERIAL AND METHODS}

\section{Preparation of the plant extract}

The whole Bacopa monnieri plant was dried in shade and then crushed. The crushed materials were 
extracted with water (Bhattacharya et al., 2000; Jyoti et al., 2007; Paulose et al., 2007). This extract was dried in vacuum. From this dried product, different concentrations $(25.0,50.0,100.0$ and $200.0 \mathrm{mg} / \mathrm{mL})$ of BM extract were prepared in $\mathrm{NaCl} 0.9 \%$ solution by established method (Oliveira et al., 2000; Moreno et al., 2004).

Female Sprague Dawley rats (250-300 g) were used. The animals were received a standard pelleted rat diet and water, and were maintained under constant environmental conditions $\left(22 \pm 5{ }^{0} \mathrm{C}, 12 \mathrm{~h}\right.$ of light/dark cycle). Experiments were conducted in accordance with the Departmental Committee of Animal Ethics and with the Institutional Guidelines of Indian Institute of Chemical Biology, Kolkata, India.

\section{In vitro radiolabeling of blood elements}

An in vitro technique employed to label $\mathrm{RBC}$ and plasma proteins (Bernardo-Filho et al., 1983, 1994a; Oliveira et al., 2000) described elsewhere was used with minor modification. Heparinized whole blood was withdrawn from Sprague Dawley rats. Blood samples of $0.5 \mathrm{~mL}$ were gently mixed and incubated with $100 \mu \mathrm{L}$ of $\mathrm{BM}$ extract at different concentrations (25.0, 50.0, 100.0 and $200.0 \mathrm{mg} / \mathrm{mL}$ ) for $1 \mathrm{~h}$ at room temperature. A sample of heparinized whole blood was incubated with $100 \mu \mathrm{L}$ of $\mathrm{NaCl} 0.9 \%$ as a control. Then, $0.5 \mathrm{~mL}$ of stannous chloride $(1.2 \mu \mathrm{g} / \mathrm{mL})$ was added and the incubation continued for another $1 \mathrm{~h}$. After this period of time, 99mTc (0.1 $\mathrm{mL})$, as pertechnetate, $\left(99 \mathrm{mTcO}^{-}\right.$used in the labeling procedure was obtained by 2-butanone extraction from a $5 \mathrm{~N} \mathrm{NaOH}$ solution of 99Mo (Misra et al., 1994)) was added and the incubation continued for another $10 \mathrm{~min}$. 99-molybdenum/99m-technetium (kits from Board of Radiation and Isotope Technology (BRIT), Mumbai, India) generator was used for radiopharmaceutical preparation. These samples were centrifuged and plasma (P) and blood cells $(\mathrm{BC})$ were separated. Samples $(20 \mu \mathrm{L})$ of $\mathrm{P}$ and $\mathrm{BC}$ were precipitated with $1.0 \mathrm{~mL}$ of trichloroacetic acid (TCA) 5\% and soluble (SF) and insoluble fractions (IF) were separated. The radioactivity in P, BC, IF-P, SF-P, IF-BC and SF-BC were determined in a well-type counter (Gamma ray spectrometer Model: GRS 23C, ECIL). After that, the percentage of radioactivity (\% ATI) was calculated, as previously described method (BernardoFilho et al., 1983; Bernardo-Filho et al., 1994a, 1994b; Oliveira et al., 2000).

The experiments were repeated ten times and the means and S.D.s were determined. A statistical analysis (Variance analysis, with significance level $\mathrm{P}<0.05, \mathrm{n}=10$ ) was utilized to compare the values found.

Histological preparations were carried out with blood samples treated with the BM extract for $60 \mathrm{~min}$ at room temperature. Blood smears were prepared, dried, fixed and staining (Junqueira \& Carneiro, 1992; Oliveira et al., 1997). After that, the morphology of the red blood cells was evaluated under an optical microscope (X1000).

\section{RESULTS}

Table 1 shows the distribution of the radioactivity in plasma and blood cells from blood treated with different concentrations of BM extracts. The analysis of the results indicates that there is a significant decrease in the uptake of $99 \mathrm{mTc}$ by the red blood cells (from $95.53 \pm 0.45$ to $35.41 \pm 0.44$ ) with the concentration of $200.0 \mathrm{mg} / \mathrm{mL}$ of the referred extracts.

Table 2 shows the distribution of the radioactivity in the insoluble fraction of plasma (IF-P) and Soluble fraction of Plasma (SF-P) obtained from whole blood treated with different concentrations of BM extracts. The analysis of the results indicates that there is a significant decrease in the radioactivity fixation of $99 \mathrm{mTc}$ in the plasma proteins (IF-P) with the BM concentration of 25 , 50,100 and $200 \mathrm{mg} / \mathrm{mL}$, and the radioactivity bound in the insoluble fraction of plasma decreased deeply from $80.20 \pm 1.16$ to $7.40 \pm 0.69$.

Table 3 shows the fixation of the radioactivity in the insoluble fraction of blood cells (IF-BC) and soluble fraction of the blood cells (SF-BC) obtained from whole blood treated with various concentrations of BM extracts. The analysis of the results indicates that there is a significant decrease in the fixation of $99 \mathrm{mTc}$ in insoluble fractions of the blood cells when all concentrations of the BM extracts are used (from $73.31 \pm 1.76$ to $21.26 \pm 1.40$ ).

The qualitative comparison of the shape of the $\mathrm{RBC}$ (not treated and treated with the BM extracts) under optical microscopy has revealed important morphological alterations due to the treatment of blood with BM extract in the different concentrations $(25,50,100$ and $200 \mathrm{mg} / \mathrm{mL})$. Figure 1 shows the histological preparation of a sample of blood (control-not treated), and Figure 2 and Figure 3 shown the histological preparations of blood treated with BM extract 25 and $200 \mathrm{mg} / \mathrm{mL}$. 
Table 1. Effect of Bacopa monnieri extract on the labeling of blood cells (BC and plasma (P) with 99mTc.

\begin{tabular}{ccc}
\hline \multirow{2}{*}{ Bacopa monnieri extract concentrations $(\mathrm{mg} / \mathrm{mL})$} & \multicolumn{2}{c}{ Percentage radioactivity (\%ATI) } \\
\cline { 2 - 3 } & Blood cells (BC) & $04.47 \pm 0.45$ \\
\hline 00.0 (control) & $95.53 \pm 0.45$ & $24.80 \pm 0.37$ \\
25.00 & $75.20 \pm 0.37$ & $38.56 \pm 0.53$ \\
100.00 & $61.44 \pm 0.53$ & $52.29 \pm 0.72$ \\
200.00 & $47.71 \pm 0.72$ & $64.59 \pm 0.44$ \\
\hline
\end{tabular}

Heparinized blood samples were incubated with different concentrations of BM extracts (25, 50, 100 and $200 \mathrm{mg} / \mathrm{mL})$. Then, stannous chloride $(1.2 \mu \mathrm{g} / \mathrm{mL})$ and $99 \mathrm{mTc}$ were added. These samples were centrifuged and plasma (P) and blood cells (BC) were separated. The radioactivity in $\mathrm{P}$ and $\mathrm{BC}$ were determined in a well counter and \% ATI in P and BC were calculated. The results were averages (S.D.s of ten isolated experiments, $\mathrm{p}<0.05$ ).

Table 2. Effect of Bacopa monnieri extract on the labeling of insoluble fraction of plasma (IF-P) and soluble fraction of plasma (SF-P) with 99mTc.

\begin{tabular}{ccc}
\hline \multirow{2}{*}{ Bacopa monnieri extract Concentrations $(\mathrm{mg} / \mathrm{mL})$} & \multicolumn{2}{c}{ Percentage radioactivity (\%ATI) } \\
\cline { 2 - 3 } & Insoluble fraction (IF-P) & Soluble fraction (SF-P) \\
\hline 00.0 (control) & $80.20 \pm 1.16$ & $33.80 \pm 1.16$ \\
25.00 & $66.28 \pm 0.51$ & $51.15 \pm 0.51$ \\
100.00 & $48.85 \pm 0.71$ & $82.89 \pm 0.55$ \\
200.00 & $17.11 \pm 0.55$ & $92.60 \pm 0.69$ \\
\hline
\end{tabular}

Heparinized blood samples were incubated with B extracts $(25,50,100$ and $200 \mathrm{mg} / \mathrm{mL})$. Then, stannous chloride $(1.2 \mu \mathrm{g} / \mathrm{mL})$ and $99 \mathrm{mTc}$ were added. These samples were centrifuged and plasma (P) and blood cells (BC) were separated. Samples $(20 \mu \mathrm{L})$ of P were precipitated with trichloroacetic acid (TCA) $5 \%$ and soluble (SF) and insoluble fractions (IF) were separated. The radioactivity in SF-P and IF-P were determined in a well counter and \% ATI in SF-P and IF-P were calculated. The results were averages (S.D.s of ten isolated experiments, $\mathrm{p}<0.05)$.

Table 3. Effect of Bacopa monnieri extract on the labeling of insoluble fraction of blood cells (IF-BC) and soluble fraction of blood cells (SF-BC) with 99mTc.

\begin{tabular}{ccc}
\hline \multirow{2}{*}{ Bacopa monnieri extract Concentrations $(\mathrm{mg} / \mathrm{mL})$} & \multicolumn{2}{c}{ Percentage radioactivity (\%ATI) } \\
\cline { 2 - 3 } & Insoluble fraction (IF-BC) & Soluble fraction (SF-BC) \\
\hline 25.0 (control) & $73.31 \pm 1.76$ & $26.69 \pm 1.76$ \\
50.00 & $54.30 \pm 1.24$ & $55.70 \pm 1.24$ \\
100.00 & $43.94 \pm 1.74$ & $70.06 \pm 1.74$ \\
200.00 & $29.45 \pm 1.23$ & $78.74 \pm 1.40$ \\
\hline
\end{tabular}

Heparinized blood samples were incubated with B extracts $(25,50,100$ and $200 \mathrm{mg} / \mathrm{mL})$. Then, stannous chloride $(1.2 \mu \mathrm{g} / \mathrm{mL})$ and $99 \mathrm{mTc}$ were added. These samples were centrifuged and plasma (P) and blood cells (BC) were separated. Samples (20 $\mu \mathrm{L})$ of BC were precipitated with trichloroacetic acid (TCA) $5 \%$ and soluble (SF) and insoluble fractions (IF) were separated. The radioactivity in SF-BC and IF-BC were determined in a well counter and \% ATI in SF-BC and IF-BC were calculated. The results were averages (S.D.s of ten isolated experiments, $\mathrm{p}<0.05$ ). 


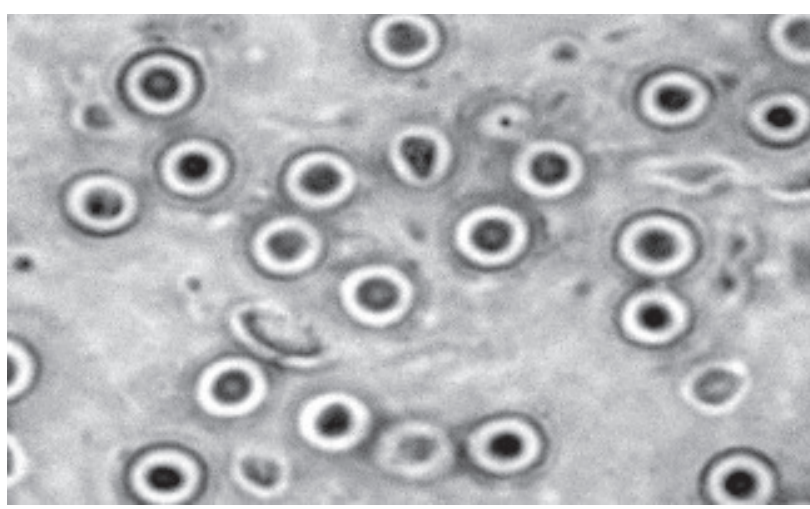

Figure 1. Photomicrography of blood smears prepared with samples of whole blood used to label RBC with 99mTc (control). Samples of whole blood were incubated with $\mathrm{NaCl} 0.9 \%$ solution for $60 \mathrm{~min}$. After that, stannous chloride solution was added and the incubation continued for $60 \mathrm{~min}$. Then $99 \mathrm{mTc}$, as sodium pertechnetate was added. Blood smears were prepared, dried, fixed and staining. After that, the morphology of the red blood cells was evaluated under an optical microscope (X1000).

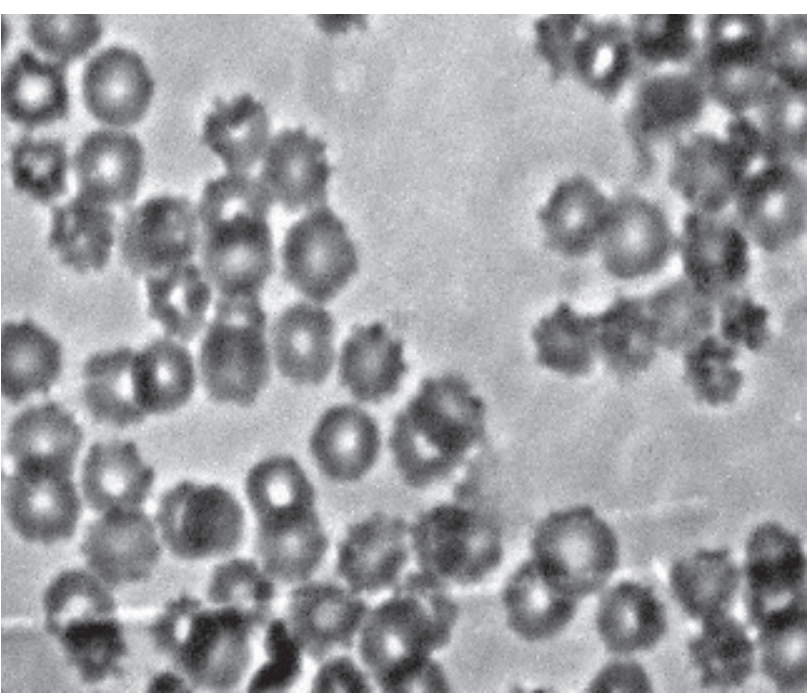

Figure 3. Photomicrography of blood smears prepared with samples of whole blood used to label RBC with $99 \mathrm{mTc}$ (blood samples were previously treated BM extract $200 \mathrm{mg} / \mathrm{mL}$ ). Samples of whole blood were incubated with BM extract $(200$ $\mathrm{mg} / \mathrm{mL}$ ) for $60 \mathrm{~min}$. After that, stannous chloride solution was added and the incubation continued for $60 \mathrm{~min}$. Then, $99 \mathrm{mTc}$, as sodium pertechnetate was added. Blood smears were prepared, dried, fixed and staining. After that, the morphology of the red blood cells was evaluated under an optical microscope (X1000).

\section{DISCUSSION}

There are evidences that various medicinal plants can affect either radiolabeling or biodistribution of red cells in the context of the nuclear medicine clinic, and a number of workers have turned their attention to in vitro testing of the drug (synthetic/natural) with 99mTC labeled blood cells (Hladik et al., 1982, 1987; Sampson, 1996; Frydman et al., 2004; Fonseca et al., 2005). Furthermore, the developing of model that permits to evaluate pharmacologic properties of natural products is worthwhile.

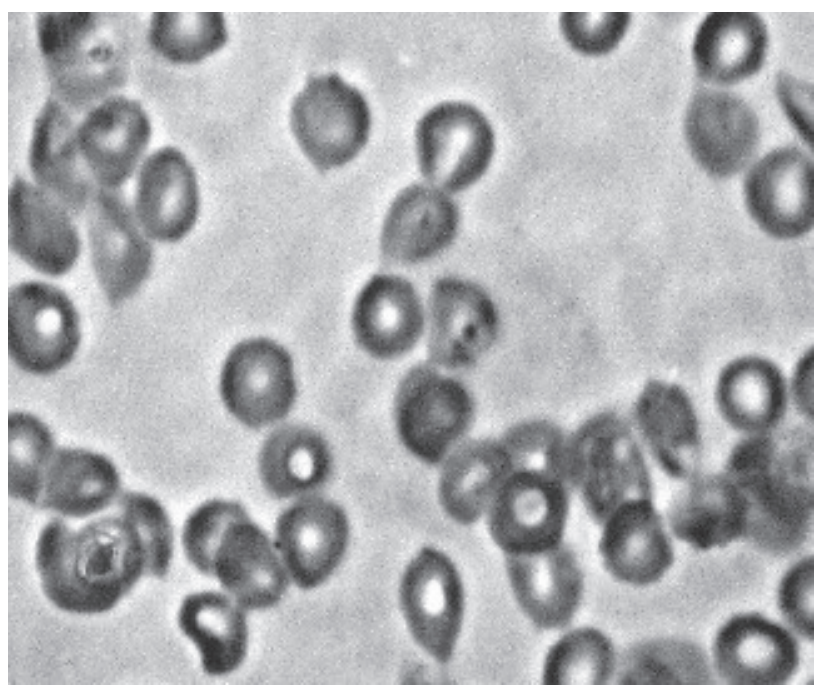

Figure 2. Photomicrography of blood smears prepared with samples of whole blood used to label RBC with $99 \mathrm{mTc}$ (blood samples were previously treated BM extract $25 \mathrm{mg} / \mathrm{mL})$. Samples of whole blood were incubated with BM extract $(25$ $\mathrm{mg} / \mathrm{mL}$ ) for $60 \mathrm{~min}$. After that, stannous chloride solution was added and the incubation continued for $60 \mathrm{~min}$. Then, $99 \mathrm{mTc}$, as sodium pertechnetate was added. Blood smears were prepared, dried, fixed and staining. After that, the morphology of the red blood cells was evaluated under an optical microscope (X1000).

The use of natural products is increasing over the world. BM extracts are used in popular medicine due to their reported important biological activities (Bhattacharya et al., 2000; Russo \& Borrelli, 2005; Kishore \& Singh, 2005; Gobindarajan et al., 2005; Jyoti et al., 2007). We have studied the BM extract effect on the labeling of RBC with $99 \mathrm{mTc}$ and the fixation of this radionuclide to insoluble fraction of plasma (plasma proteins) and blood cells (blood cells proteins). The results of this study showed that BM extracts reduced the fixation of radioactivity in plasma proteins and blood proteins.

In this labeling process, labeling of RBC with $99 \mathrm{mTc}$ depends on the entry of stannous and pertechnetate ions into these cells through ionic channels (Callahan \& Rabito, 1990). Then, as reported to the tobacco extracts (Vidal et al., 1998), Maytenus ilicifolia (Oliveria et al., 2000), Sechium edule (Dire et al., 2003), Mentha crispa (Santos-Filho et al., 2002), Paullina cupana (Oliveira et al., 2002), Gingko biloba (Moreno et al., 2002, 2004), Fucus vesiculosus (Oliveira et al., 2003a) and Psidium guajava (Abreu et al., 2006) extracts, histological alterations of red blood cells could be responsible for the modifications on the labeling of RBC with 99mTc. However, the results obtained with the qualitative comparison of the shape of the RBC (not treated and treated with natural extracts) under optical microscopy did not justify the modifications in the uptake of $99 \mathrm{mTc}$ by the red blood cells in presence of BM extracts. The achieved results have revealed only lightly morphological alterations due to the treatment of blood with BM extracts in the concentrations of 25 and $200 \mathrm{mg} / \mathrm{mL}$. 
It is described that natural and synthetic products can alter the labeling of blood constituents with $99 \mathrm{mTc}$ (Frydman et al., 2004; Valenca et al., 2005; Fonseca et al., 2005). The labeling of blood constituents could decrease due to the action of drugs (natural and synthetic) in (1) binding at the same sites on the blood constituents, (2) direct inhibition (chelating action) of the stannous $\left(\mathrm{Sn}^{+2}\right)$ and pertechnetate ions $\left(99 \mathrm{mTcO}^{-}\right)$, (3) direct oxidation or generation of free radicals that could oxidize the stannous ion, (4) antioxidant action impeding or decreasing the stannous ion oxidation, and (5) alteration of the plasma membrane structure or modifying the transport systems of stannous and pertechnetate ions into cells.

As in this radiolabelling process of red blood cells with $99 \mathrm{mTc}$ depends on the entry of stannous and pertechnetate ions into these cells through plasma membrane (Callahan \& Rabito, 1990; Gutfilen et al., 1993), we suggest that $\mathrm{BM}$ extracts effect (decrease in the fixation of the radioactivity on RBC, IF-P and IF-BC) might be explained by an inhibition of the transport of these ions, or oxidation of the stannous to stannic ion or by damages induced in plasma membrane or by generating of ROS, as already reported by other medicinal plant extracts (Vidal et al.,1998; Oliveria et al., 2003a, 2003b; Santos-Filho et al., 2004; Moreno et al., 2004; Abreu et al., 2006).

\section{CONCLUSION}

In conclusion, our experimental results indicates that $99 \mathrm{mTc}-\mathrm{RBC}, 99 \mathrm{mTc}-\mathrm{IF}-\mathrm{P}$ and $99 \mathrm{mTc}-\mathrm{IF}-\mathrm{BC}$ can be decreased in presence of $\mathrm{BM}$ extract and we can suggest that this effect may be due to the active compounds presents in this Bacopa monnieri extracts that may (i) complex with these ions (stannous and pertechnetate), or (ii) have direct or an indirect effect on intracellular stannous ion concentration. Experiments with different extracts of medicinal plants are in progress to evaluate the possibility of the generation of these free radicals. Furthermore, this study suggest that the aqueous extracts of Bacopa monnieri could present antioxidant action and/or effects on the membrane structures involved in ions transport altering the radiolabeling of blood constituents with $99 \mathrm{mTc}$ and that precaution should be taken in examinations of nuclear medicine based on this procedure in patients using Bacopa monnieri extracts.

\section{ACKNOWLEDGMENTS}

We are thankful to Indian Council of Medical Research (ICMR), New Delhi, India for providing financial support.

\section{REFERENCES}

Abreu PRC, Almeida MC, Bernardo RM, Bernardo LC, Brito LC, Garcia EAC, Fonseca AS, Bernardo-Filho M 2006. Guava extract (Psidium guajava) alters the labelling of blood constituents with technetium-99m. J Zhejiang Univ Sci B 7: 429-435.

Aquino TM, Amorim ELC, Feliciano GD, Lima EAC, Gomes ML, Lima CSA, Albuquerque UP, Bernardo-Filho M 2007. Influence of biflorin on the labelling of red blood cells, plasma protein, cell protein, and lymphocytes with technetium-99m: in vitro study. Rev Bras Farmacogn 17: 181-185.

Atkins HL, Klopper JF, Ansari AN, Meinken G, Richerds P, Srivastava S 1980. A comparison of Tc-99m labeled human serum albumin and in vitro labled red blood pool studies. Clin Nucl Med 5: 166-169.

Barbosa-Filho JM, Nascimento-Júnior FA, Tomaz ACA, Athayde-Filho PF, Silva MS, Cunha EVL, Souza MFV, Batista LM, Diniz MFFM 2007. Natural products with antileprotic activity. Rev Bras Farmacogn 17: 141-148.

Bernardo-Filho M, Moura INN, Boasquevisque EM 1983. Technetium-99m-labeled red blood cells in vitro. Arq Biol Tecnol 26: 455-461.

Bernardo-Filho M, Gutfilen B, Maciel OS 1994a. Effect of different anticoagulants on the labeling of red blood cells ans plasma proteins with technetium-99m. Nucl Med Commun 15: 730-734.

Bernardo-Filho M, Gutfilen B, Maciel OS 1994b. Technetium$99 \mathrm{~m}$ binding on plasma proteins and red blood cells : role of various precipitating agents. Biomed Lett 50: 17-24.

Bhattacharya SK, Bhattacharya A, Kumar A, Ghosal S 2000. Antioxidant activity of Bacopa monniera in rat frontal cortex, striatum and hippocampus. Phytother Res 14: 174-179.

Biavatti M, Marensi V, Leite SN, Reis A 2007. Ethnopharmacognostic survey on botanical compendia for potential cosmeceutic species from Atlantic Forest. Rev Bras Farmacogn 17: 640-653.

Braga ACS, Oliveira MBN, Feliciano GD, Reiniger IW, Oliveir JF, Silva CR, Bernardo-Filho M 2000. The effect of drugs on the labeling of blood rlements with technetium-99m. Curr Pharm Design 6: 1179-1191. This reference is no cited!

Callahan RJ, Rabito CA 1990. Radiolabeling of erythrocytes with technetium-99m: role of band-3 protein in the transport of pertechnetate across the cell membrane. $J$ Nucl Med 31: 2044-2045.

Cardoso-Lopes EM, Carreira RC, Agripino DG, Torres LMB, Cordeiro I, Bolzani VS, Dietrich SMC, Young MCM 2008. Screening for antifungal, DNA-damaging and anticholinesterasic activities of Brazilian plants from the Atlantic Rainforest - Ilha do Cardoso State Park. Rev Bras Farmacogn 18 (Supl.): 655-660.

Chowdhuri DK, Parmer D, Kakkar P, Shukla R, Seth PK, Srimal RC 2002. Antistress effects of bacosides of Bacopa monnieri: modulation of Hsp 70 expression, superoxide dismutase and cytochrome P450 activity in rat brain. Phytother Res 16: 639-645.

Dewanjee MK, Rao SA, Penniston JT 1982. Mechanism of red blood cell labeling with $99 \mathrm{mTc}$ pertecnetate and the role of cation pumps at RBC membrane on distribution and 
binding of $\mathrm{Sn}^{+2}$ and $99 \mathrm{mTc}$ with membrane proteins and hemoglobin. J Labelled Compd Rad 11: 1464-1466.

Dire GF, Lima E, Gomes ML, Moreno S, Faria MVC, Jales RL, Catanho MTJA, Bernardo-Filho M 2003. Evaluation of the biological effects of a natural extract of chayotte (Sechium edule): A molecular and cellular analysis. Pakistan J Nutr 2: 249-253.

Dire GF, Lima E, Gomes ML, Lima EAC, Jales RL, Faria MC, Bernardo-Filho M 2004. Essessment of a fruit extract (Sechium edule) on the labeling of blood elements with technetium-99m. Afr J Biotechnol 3: 484-488. This reference is no cited!

Early PJ, Sodee DB 1999. Principles and Practice of Nuclear Medicine, Mosby Year Book, p. 94-110.

Fonseca AS, Frydman JNG, Santos R, Bernardo-Filho M 2005. Influence of antipyretic drugs on the labeling of blood elements with technetium-99m. Acta Biol Hung 56: 275282.

Frydman JNG, Oliveira MBN, Santos AEO, Fonseca AS, Santos R, Bernardo-Filho M 2004. Influence of methylxanthines on the labelling of blood elements with $99 \mathrm{~m}$ Tc. Pakistan J Biol Sci 4: 249-253.

Govindarajan R, Vijayakumar M, Pushpangadan P 2005. Antioxidant approach to disease management and the role of 'Rasayana' herbs of Ayurveda. J Ethonopharmacol 99: 165-178.

Gutfilen B, Boasquevisque EM, Bernardo-Filho M 1993. Calcium channel blockers: interference on red blood cell and plasma protein labeling with Tc-99m. Rev Esp Med Nuclear 11: 195-199.

Harbert JC, Eckelman WC, Neumann RD 1996. Nuclear medicine diagnosis and therapy. Thieme Medical Publishers, Inc., New York.

Hesselewood S, Leung E 1994. Drug interactions with radiopharmaceuticals. Eur J Nucl Med 21: 348-356.

Hladik WB III, Nigg KKE, Rhodes BA 1982. Drug-induced changes in the biologic distribution of radiopharmaceuticals. Semin Nucl Med 9: 184-192.

Hladik WB III, Saha GB, Study KT 1987. Essentials of nuclear medicine science. William and Wilkins, London.

Joyti A, Sethi P, Sharma D 2007. Bacopa monniera prevents from aluminium neurotoxicity in the cerebral cortex of rat brain. J Ethnopharmacol 111: 56-62.

Junqueira LC, Carneiro J 1992. Histologia Basica. Rio de Janeiro: Guanabara Koogan.

Kishore K, Singh M, 2005. Effect of bacosides, alcoholic extract of Bacopa monniera Linn.(Brahmi), on experimental amnesia in mice. Indian J Exp Biol 43: 640-645.

Mariath IR, Falcão HS, Barbosa-Filho JM, Sousa LCF, Tomaz ACA, Batista LM, Diniz MFFM, Athayde-Filho PF, Tavares JF, Silva MS, Cunha EVL 2009. Plants of the American continent with antimalarial activity. Rev Bras Farmacogn 19: 158-192.

Misra M, Das BK, Gambhir S, Mittal BR, Sewatkar AB, Ghosh S, Banerjee SN 1994. Clinical evaluation of Tc-99m cystine a new renal radiopharmaceutical. Clin Nucl Med 19: 314-320.

Moreno SRF, Dire GF, Freitas RS, Farah MB, Lima-Filho GL, Rocha EK, Jales RLC, Bernardo-Filho M 2002. Effect of Ginkgo biloba on the labeling of blood elements with technetium-99m: in vitro study. Rev Bras Farmacogn 12: 62-63.

Moreno SRF, Freitas RS, Rocha EK, Lima-Filho GL, Bernardo-
Filho M 2004. Protection of plasmid DNA by a Ginkgo biloba extract from the effects of stannous chloride and the action on the labeling of blood elements with technetium-99m. Braz J Med Biol Res 37: 267-271.

Mousinho KC, Correia MBL, Barros ALS, Magnata SSLP, Souza IA, Catanho MTJA 2009. Avaliação do controle radioquímico do Ricinus communis L. e Tc-99m na marcação de hemácias. Rev Bras Farmacogn 19: 449-451.

Oliveira JF, Braga ACC, Avila AS, Fonseca LMB, Gutfilen B, Bernardo-Filho M 1997. Effect of Thuya occidentalis on the labeling of red blood cells and plasma proteins with technetium-99m. Yale J Biol Med 69: 489-494.

Oliveira JF, Braga ACS, Oliveira MBN, Avila AS, Cardoso VN, Bezerra ACR, Bernardo-Filho M 2000. Assesment of the effect of Maytenus ilicifolia (espinheira santa) extract on the labeling of red blood cells and plasma proteins with technetium-99m. J Ethnopharmacol 72: 179-184.

Oliveira JF, Avila AS, Braga ACC, Oliveira MBN, Boasquevisque EM, Jales RL, Cardoso VN, Bernardo-Filho M 2002. Effect of extract of medicinal plants on the labeling of blood elements with technetium-99m and on the morphology of red blood cells: I-a study with Paullinia cupana. Fitoterapia 73: 305-312.

Oliveira JF, Oliveira MBN, Avila AS, Braga ACS, Catanho MTJA, Jales RLC, Cardoso VN, Bernardo-Filho M 2003a. Assesment of the effect of Fucus vesiculosos extract on the labeling of blood constituents with tchnetium-99m and the histological modification on the shape of the red blood cells. Food Chem Toxicol 41: 15-20.

Oliveira JF, Santos-Filho SD, Catanho MTJA, Srivastava SC, Lima-Filho GL, Bernardo-Filho M 2003b. Effect of extract of medicinal plants on the labeling of blood elements with technetium-99m and on the morphology of red blood cells (RBC): toxicological actions of roast coffee beans (Coffea arabica). Indian J Nucl Med 18: 52-56.

Paoli S, Dias APM, Capriles PVSZ, Costa TEMM, Fonseca AS, Bernardo-Filho M 2008. Effects of a tomato (Solanum lycopersicum) extract on the labeling of blood constituents with technetium-99m. Rev Bras Farmacogn 18: 190-196.

Paulose CS, Chathu F, Khan SR, Krishnakumar A 2008. Neuroprotective role of Bacopa monnieri extract in epilepsy and effect of glucose supplementation during hypoxia: glutamate receptor gene expression. Neurochem Res 33: 1663-1671.

Porter WC, Dees SM, Freitas JE 1993. Acid-citrate-dextrose compared with heparin in the preparation of in vivo/in vitro technetium-99m red blood cells. J Nucl Med 24: 383-387.

Quintans-Júnior LJ, Almeida JRGS, Lima JT, Nunes XP, Siqueira JS, Oliveira LEG, Almeida RN, Athayde-Filho PF, Barbosa-Filho JM 2008. Plants with anticonvulsant properties - a review. Rev Bras Farmacogn 18 (Supl.): 798-819.

Rangel LP, Abreu LF, Andrade AR, Leitão SG, Leitão GG, Ferreira-Pereira A 2008. Effect of different extracts from the Brazilian Atlantic Forest on the Pdr5p ATPase activity. Rev Bras Farmacogn 18: 30-36.

Rodríguez M, Hasegawa M, González-Mújica F, Motta N, Castillo A, Castillo J, Zea E, Mora K, Sousa L, González A, Camejo D 2008. Antidiabetic and antiradical activities of plants from Venezuelan Amazon. Rev Bras Farmacogn 18: 331-338. 
Russo A, Borrelli F 2005. Bacopa monniera, a reputed nootropic plant: an overview. Phytomedicine 12: 305-317.

Saha GB 2003. Normal biodistribution of diagnostic radiopharmaceuticals. In: Hladik WB, Saha GB, Study KT (Eds.), Essentials of Nuclear Medicine Science: Williams and Wilkins, Baltimore, USA, p. 3-19.

Sampson CB 1996. Complications and difficulties in radiolabeling blood cells: a Review. Nucl Med Commun 17: 648658.

Santos JC, Paula EF, Correa TG, Freitas LC, Fonseca LM, Gutfilen B, Bernardo-Filho M 1995. Effect of cyclophosphamide on the binding of 99mTcO4- and 99mTc-MDP to blood cells and plasma proteins. Braz J Med Biol Res 28: 131-135.

Singh HK, Dhawan BN 1992. Drugs affecting learning and memory. In Lectures in Neurobiology, vol. 1, ed. by Tandon PN, Bijiani V, Wadhwa S. Wiley Eastern: New Delhi. p. 189-207.

Sousa FCF, Melo CTV, Citó MCO, Félix FHC, Vasconcelos SMM, Fonteles MMF, Barbosa-Filho JM, Viana GSB 2008. Plantas medicinais e seus constituintes bioativos: Uma revisão da bioatividade e potenciais benefícios nos distúrbios da ansiedade em modelos animais. Rev Bras Farmacogn 18: 642-654.

Srivastava SC, Straub RF, Richards P 1984. Mechanistic aspects of the technetium-99m-tin-RBC labeling reactions. $J \mathrm{La}$ belled Compd Rad 21: 1055-1058.

Srivastava S 1987. State of the art (and science) of blood cell labeling. Brookhaven Lec Series 232: 1-14.

Srivastava SC, Straub RF 1992. Evaluation of heparin and anticoagulant citrate dextrose in the preparation of technetium-99m-red blood cell with Ultra Tag RBC Kit. Reply. J Nucl Med 33: 307-308.

Valenca SS, Lima EAC, Dire GF, Bernardo-Filho M, Porto LC 2005. Sodium pertechnetate $(\mathrm{Na} 99 \mathrm{mTcO} 4)$ biodistribution in mice exposed to cigarette smoke. BMC Nucl Med 5: 1 .

Vidal MV, Gutfilen B, Fonseca LMB, Bernardo-Filho M 1998. Influence of tobacco on the labelling of red blood cells and plasma proteins with technetium-99m. J Exp Clin Cancer Res 17: 41-46. 